\title{
Peran Profitabilitas dalam Memoderasi Pengaruh Predictor Peringkat Obligasi
}

\author{
Andreani Caroline Barus \\ STIE Mikroskil \\ Medan, Indonesia \\ andreani@mikroskil.ac.id
}

\author{
Anita Tarihoran \\ STIE Mikroskil \\ Medan, Indonesia \\ anita.tarihoran@mikroskil.ac.id
}

Submitted: 11 Juni 2020

Accepted: 1 Agustus 2020

Published: 1 Agustus 2020

\begin{abstract}
ABSTRAK
Penelitian ini bertujuan agar dapat mengetahui dan menganalisis pengaruh Likuiditas, Leverage dan Ukuran Perusahaan sebagai variabel independen, secara simultan dan parsial terhadap Peringkat Obligasi sebagai variabel dependennya, dengan Profitabilitas sebagai variabel moderasi. Penelitian ini berdasarkan pada perusahaan publik non keuangan yang terdaftar di PEFINDO periode 2016-2018. Populasi perusahaan tersebut yang diperoleh berjumlah 60 perusahaan. Menggunakan metode purposive sampling diperoleh sebanyak 78 perusahaan sampel. Metode pengujian data penelitian menggunakan analisis regresi linear berganda. Secara simultan, Ukuran Perusahaan berpengaruh signifikan terhadap Peringkat Obligasi. Secara parsial, Likuiditas dan Leverage tidak berpengaruh terhadap Peringkat Obligasi. Profitabilitas tidak mampu memoderasi hubungan antara Likuiditas, Leverage dan Ukuran Perusahaan terhadap Peringkat Obligasi.
\end{abstract}

Kata kunci : Peringkat Obligasi, Leverage, Profitabilitas, Likuiditas, Ukuran Perusahaan

\section{PENDAHULUAN}

Sumber pembiayaan merupakan bagian penting untuk kelangsungan hidup suatu usaha khususnya untuk melakukan ekspansi usaha dan sarana untuk memperkuat modal perusahaan. Salah satu bentuk pendanaan yang dapat dilakukan oleh perusahaan adalah dengan penerbitan obligasi. Obligasi menarik dan diminati oleh investor karena memiliki kelebihan yaitu pemegang obligasi memiliki hak pertama atas asset perusahaan jika perusahaan mengalami likuidasi (Brigham \& Huoston, 2010). Seperti jenis investasi lainnya, obligasi juga tidak lepas dari risiko. Risiko ini dapat diminimalisir melalui peringkat obligasi yang dikeluarkan oleh perusahaan pemeringkat independen seperti Perusahaan Efek Indonesia (PEFINDO). Peringkat obligasi dibuat untuk memberikan informasi kepada para investor apakah investasi mereka terutama dalam bentuk obligasi merupakan investasi yang berisiko atau tidak, serta memberikan pernyataan yang informatif dan memberikan sinyal tentang probabilitas kegagalan hutang suatu perusahaan (Sitorus, 2015).

Peringkat obligasi bagi perusahaan yang terdaftar di PEFINDO tidak selamanya berada dirating yang baik. Hal ini dapat dilihat pada PT Trikomsel Oke Tbk (TRIO) gagal membayar senior fixed rate notes senilai US\$ 100 juta dengan tingkat bunga $7,875 \%$ dan jatuh tempo 
Desember 2017. Selain itu, terdapat utang obligasi lainnya jatuh tempo November 2016 senilai US\$ 115 juta dengan kupon 5,25\% membuat PT Pemeringkat Efek Indonesia (PEFINDO) menurunkan peringkat TRIO dari idCCC menjadi idSD (selective default). Dalam kasus lain, PT Express Transindo Utama Tbk (TAXI) gagal membayar bunga ke-15 obligasi tahun 2014 sebesar $12,25 \%$ dengan jumlah obligasi Rp 993,24 juta kepada pemegang obligasi $\mathrm{I} / 2014$ pada 26 Maret 2018. Atas kegagalan tersebut, Pemeringkat Efek Indonesia (PEFINDO) menurunkan peringkat obligasi Express Transindo Utama dari BB- menjadi D (default)

Berdasarkan kasus yang telah diuraikan, diketahui terdapat beberapa emiten yang mengalami penurunan peringkat obligasi akibat kondisi kesehatan keuangan yang kurang baik. Oleh sebab itu, para investor yang hendak melakukan investasi terhadap obligasi suatu perusahaan harus memperhatikan peringkat obligasi dari perusahaan tersebut. Dalam pemberian peringkat obligasi rasio keuangan dapat mempengaruhi peringkat obligasi dipasar.

Rasio profitabilitas merupakan rasio yang menggambarkan kemampuan perusahaan dalam menghasilkan laba melalui semua kemampuan dan sumber daya yang dimilikinya, yaitu yang berasal dari kegiatan penjualan, penggunaan aset, maupun penggunaan modal. Semakin tinggi hasil pengembalian atas aset berarti semakin tinggi pula jumlah laba bersih yang dihasilkan dari setiap rupiah dana yang tertanam dari total aset (Brigham \& Huoston, 2010). Hal ini berarti perusahaan mampu menghasilkan laba dimana menyebabkan nilai risiko kegagalan pembayaran obligasi juga akan rendah sehingga peringkat obligasi perusahaan tersebut juga akan meningkat.

Rasio likuiditas bertujuan untuk mengukur kemampuan perusahaan dalam memenuhi kewajiban jangka pendek.
Rasio likuiditas yang tinggi mencerminkan kondisi keuangan perusahaan yang kuat sehingga mampu melunasi kewajiban yang ada yang berdampak pada meningkatnya peringkat oligasi. Hal ini didukung pleh penelitian (Sari \& Badjra, 2016) yang mengatakan likuiditas berpengaruh terhadap peringkat obligasi sementara penelitian (Fauziah, 2014). mengungkapkan bahwa likuiditas tidak berpengaruh terhadap peringkat obligasi. Profitabilitas yang meningkat menunjukkan kemampuan perusahaan dalam menghasilkan laba juga meningkat, hal ini berdampak pada meningkatnya jumlah asset yang dimiliki perusahaan yang pada akhirnya akan mempengaruhi peringkat obligasi perusahaan.

Informasi rasio leverage penting karena melalui rasio utang, investor dapat mengukur seberapa tinggi risiko utang yang diberikan kepada suatu perusahaan. Apabila suatu perusahaan pembiayaannya lebih banyak menggunakan utang, hal ini akan berisiko terjadi kesulitan pembayaran di masa yang akan datang akibat utang lebih besar dari modal yang dimiliki dan akan mempengaruhi peringkat obligasi perusahaan. Pada hasil penelitian terdahulu mengungkapkan bahwa Leverage berpengaruh terhadap peringkat obligasi (Azani, Khairunnisa, \& Dillak, 2017) sedangkan penelitian lainnya mengungkapkan bahwa Leverage tidak berpengaruh terhadap peringkat obligasi (Sihombing \& Rachmawati, 2015). Kemampuan menghasilkan laba yang meningkat dapat meyakinkan investor jika perusahaan mampu melunasi hutang yang dimiliki, hal ini akan menyebabkan peringkat obligasi dipasar tidak mengalami penurunan.

Ukuran perusahaan membantu investor untuk mengetahui kemampuan perusahaan dalam membayar bunga obligasi. Perusahaan kecil memiliki risiko yang lebih besar dibandingkan dengan perusahaan besar karena aset yang dimiliki perusahaan besar relatif lebih 
banyak jumlahnya. Hal ini dikukung oleh penelitian (Sari \& Badjra, 2016) yang mengatakan ukuran perusahaan berpengaruh positif dan signifikan terhadap peringkat obligasi sedangkan penelitian lainnya mengungkapkan bahwa ukuran perusahaan tidak berpengaruh terhadap peringkat obligasi (Wijayanti \& Priyadi, 2014). Perusahaan dalam kategori besar cenderung memiliki return yang lebih tinggi dibanding perusahaan dalam kategori kecil. Hal ini berdampak pada meningkatnya jumlah asset yang bisa dijadikan jaminan kepada investor sehingga peringkat obligasi akan meningkat.

Berdasarkan penjabaran tersebut terdapat beberapa hal yang dapat mempengaruhi peringkat obligasi perusahaan, sehingga peneliti tertarik mengambil penelitian yang berjudul "Peran Profitabilitas dalam Memoderasi Pengaruh Predictor Peringkat Obligasi Pada Perusahaan Publik Non Keuangan Yang Terdaftar Di PEFINDO Periode 2016-2018”

\section{KAJIAN PUSTAKA}

\subsection{Peringkat Obligasi}

Peringkat Obligasi merupakan skala risiko dari semua obligasi yang diperdagangkan. Skala tersebut menunjukkan tingkat keamanan suatu obligasi bagi investor. Keamanan ini ditunjukkan oleh kemampuan emiten sebagai penerbit obligasi dalam membayar bunga dan pelunasan pokok obligasi pada akhir masa jatuh temponya (Hery, 2017). Pengukuran variabel ini menggunakan Peringkat Obligasi (Novita, 2018 \& Pefindo, 2019).

\subsection{Profitabilitas}

Rasio profitabilitas merupakan rasio yang menggambarkan kemampuan perusahaan dalam menghasilkan laba melalui semua kemampuan dan sumber daya yang dimilikinya, yaitu yang berasal dari kegiatan penjualan, penggunaan aset, maupun penggunaan modal. Return on Assets (ROA) merupakan rasio yang mengukur kemampuan perusahaan menghasilkan laba bersih berdasarkan tingkat aset yang tertentu (Brigham \& Huoston, 2010).

$$
\text { ROA }=\frac{\text { Laba bersih }}{\text { Total Aset }}
$$

\subsection{Likuiditas}

Likuiditas adalah kemampuan suatu perusahaan memenuhi kewajiban keuangannya dalam jangka pendek atau kemampuan perusahaan untuk memenuhi kewajiban keuangan pada waktu ditagih. Current Ratio (CR) adalah perbandingan antara aktiva lancar dan utang lancar serta ukuran yang paling umum digunakan untuk mengetahui kemampuan suatu perusahaan dalam memenuhi kewajiban jangka pendeknya (Brigham \& Huoston, 2010). .

$$
\mathrm{CR}=\frac{\text { Aktiva Lancar }}{\text { Utang Lancar }}
$$

\subsection{Leverage}

Leverage merupakan perbandingan besarnya dana yang disediakan pemiliknya dengan dana yang dipinjam dari kreditur. Leverage menggambarkan kondisi struktur modal perusahaan untuk melihat potensi risiko dari tak tertagihnya suatu hutang. Debt to Equity Ratio (DER) merupakan rasio yang berguna untuk mengetahui jumlah dana yang disediakan peminjam (kreditur) dengan pemilik perusahaan (Kasmir, 2018).

\subsection{Ukuran Perusahaan}

$$
\text { DER }=\frac{\text { Total Utang }}{\text { Total Ekuitas }}
$$

Ukuran perusahaan atau firm size adalah tolak ukur besar kecilnya perusahaan dengan melihat besarnya nilai ekuitas, nilai penjualan atau nilai total aset yang dimiliki perusahaan. Ukuran perusahaan menentukan kekuatan tawar menawar (bergaining Power) dalam kontrak keuangan (Hartono, 2017).

$$
\text { SIZE }=\operatorname{Ln}(\text { Total Aktiva) }
$$




\subsection{Pengembangan Hipotesis} adalah Hipotesis dalam penelitian ini

a. Likuiditas, leverage dan ukuran perusahaan berpengaruh secara simultan dan parsial terhadap peringkat obligasi pada perusahaan publik non keuangan yang terdaftar di PEFINDO periode 2016-2018

b. Profitabilitas mampu memoderasi hubungan antara likuiditas, leverage dan ukuran perusahaan dengan peringkat obligasi pada perusahaan publik non keuangan yang terdaftar di PEFINDO periode 2016-2018

\section{METODE PENELITIAN}

Jenis penelitian yaitu deskriptif kuantitatif. Penelitian deskriptif kuantitatif merupakan usaha sadar dan sistematis untuk memberikan jawaban terhadap suatu masalah dan/atau mendapatkan informasi lebih mendalam dan luas terhadap suatu fenomena dengan menggunakan tahap-tahap penelitian dengan pendekatan kuantitatif (Ghozali, 2013). Teknik pengumpulan data dilakukan dengan dua tahap yaitu, studi pustaka dengan mengumpulkan informasi dari artikel, jurnal akuntansi, dan bukubuku yang berkaitan dengan penelitian ini dan studi dokumentasi dengan mengumpulkan data laporan keuangan perusahaan publik non keuangan yang terdaftar di PEFINDO periode 2016-2018.

Tabel 1 Prosedur Pemilihan Sampel

\begin{tabular}{lc}
\hline \multicolumn{1}{c}{ Keterangan } & Jumlah \\
\hline Populasi: & 60 \\
Perusahaan non keuangan & 60 \\
go public yang terdaftar di & \\
PEFINDO pada periode & \\
2016-2018 & \\
\hline Kriteria: &
\end{tabular}

\section{Kriteria:}

a. Perusahaan publik non keuangan yang tidak mendapatkan peringkat

\begin{tabular}{ll}
\hline \multicolumn{3}{c}{ Keterangan } & Jumlah \\
\hline obligasi di PEFINDO & \\
secara berturut-turut & \\
selama periode 2016- & \\
& 2018 \\
b. & $\begin{array}{l}\text { Perusahaan publik non } \\
\text { keuangan yang tidak } \\
\text { memperoleh laba secara }\end{array}$ \\
berturut-turut selama & \\
periode 2016-2018 \\
c. Perusahaan publik non \\
keuangan (3) \\
menyajikan laporan \\
keuangan dalam mata \\
uang USD \\
\hline Jumlah Sampel \\
\hline Jumlah Pengamatan (26 x 3 \\
tahun)
\end{tabular}

Metode analisis data yang digunakan dalam penelitian ini adalah metode analisis statistik dengan bantuan program SPSS. Dalam penelitian ini digunakan model regresi linear berganda dan uji selisih yang terlebih dahulu dilakukan pengujian asumsi klasik.

\section{HASIL DAN PEMBAHASAN}

\subsection{Uji Asumsi Klasik}

Dari pengujian asumsi klasik yang dilakukan, data yang digunakan dalam peneelitian memenuhi seluruh rangkaian uji asumsi klasik, baik itu Uji Normalitas, Uji Multikolinearitas, Uji Heteroskedastisitas dan Uji Autokorelasi.

\subsection{Pengujian Hipotesis Pertama}

Tabel 3 Uji Signifikansi Simultan (Uji-F)

\begin{tabular}{|l|l|l|l|l|l|l|}
\hline & $\begin{array}{l}\text { Sum } \\
\text { of } \\
\text { Square } \\
\text { S }\end{array}$ & $\begin{array}{l}\text { Mean } \\
\text { d } \\
\text { f }\end{array}$ & $\begin{array}{l}\text { Squar } \\
\text { e }\end{array}$ & F & Sig. \\
\hline 1 & $\begin{array}{l}\text { Regressi } \\
\text { on }\end{array}$ & 60.621 & 3 & $\begin{array}{l}20.20 \\
7\end{array}$ & $\begin{array}{l}4.70 \\
8\end{array}$ & $\begin{array}{l}.00 \\
5^{\text {a }}\end{array}$ \\
\hline Residual & 317.59 & 7 & 4.292 & & \\
\hline & 7 & 4 & & & \\
\hline Total & $\begin{array}{l}378.21 \\
8\end{array}$ & 7 & 7 & & \\
\hline
\end{tabular}


Berdasarkan Tabel 3, dapat dilihat bahwa nilai $\mathrm{F}$ hitung sebesar 4,708 sedangkan $\mathrm{F}$ tabel 2,73. Berdasarkan nilai tersebut, maka dapat disimpulkan (F hitung $=4,708)>(\mathrm{F}$ tabel $=2,73)$ dengan nilai signifikansi lebih kecil dari 0,05 $(0,005<0,05)$. Dengan demikian, dapat dikatakan bahwa $\mathrm{H}_{0}$ ditolak dan $\mathrm{H}_{1}$ diterima yang berarti Likuiditas, Leverage dan Ukuran Perusahaan secara simultan berpengaruh terhadap Peringkat Obligasi pada perusahaan publik non keuangan yang terdaftar di PEFINDO periode 20162018.

Tabel 4 Uji Signifikansi Parsial (Uji-t)

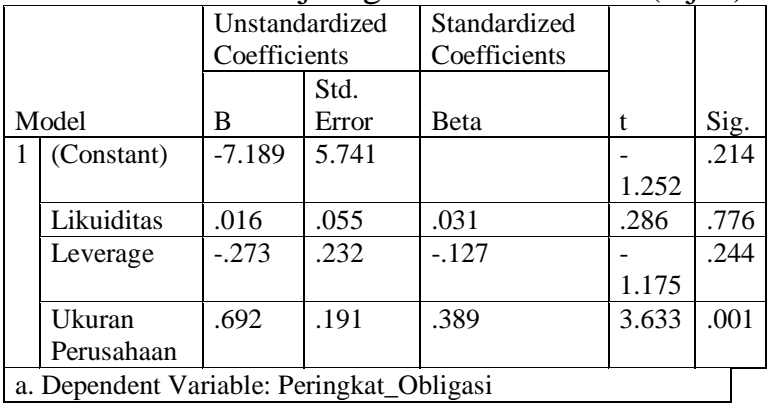

Berdasarkan Uji parsial (Uji t) nilai $\mathrm{t}_{\text {hitung dapat dilihat pada Tabel } 4 \text {, dimana }}$ nilai $t_{\text {tabel }}$ adalah 1,66571 dengan nilai probability sebesar 0,05 dengan nilai $\mathrm{df}$ sebesar 74. Jika $t_{\text {hitung }}>t_{\text {tabel }}$ dan tingkat signifikansi yang diperoleh lebih kecil

dari 0,05 maka $\mathrm{H}_{0}$ ditolak dan $\mathrm{H}_{1}$ diterima.

Hasil pengujian Uji t berdasarkan Tabel 4 dapat disimpulkan sebagai berikut:

1. Pengaruh Likuiditas terhadap Peringkat Obligasi

Berdasarkan perhitungan uji parsial yang diperoleh dari Tabel 4, dapat diketahui bahwa nilai $t_{\text {hitung }}=0,286<$ nilai $t_{\text {tabel }}$ 1,66571 dan nilai signifikansi yang diperoleh adalah 0,776 >0,05, maka $\mathrm{H}_{0}$ diterima $\mathrm{H}_{1}$ ditolak, yang artinya variabel Likuiditas tidak berpengaruh signifikan terhadap Peringkat Obligasi pada perusahaan publik non keuangan yang terdaftar di PEFINDO periode 2016-2018.

\section{Pengaruh Leverage terhadap Nilai Perusahaan}

Berdasarkan perhitungan uji parsial yang diperoleh dari Tabel 4, dapat diketahui bahwa nilai $t_{\text {hitung }}=|-1,175|<$ nilai $t_{\text {tabel }}$ 1,66571 dan nilai signifikansi yang diperoleh adalah $0,244>0,05$, maka $\mathrm{H}_{0}$ diterima $\mathrm{H}_{1}$ ditolak, yang artinya variabel Leverage tidak berpengaruh signifikan terhadap Peringkat Obligasi pada perusahaan publik non keuangan yang terdaftar di PEFINDO periode 2016-2018.

\section{Pengaruh Ukuran Perusahaan} terhadap Nilai Perusahaan

Berdasarkan perhitungan uji parsial yang diperoleh dari Tabel 4, dapat diketahui bahwa nilai $t_{\text {hitung }}=3,633>$ nilai $t_{\text {tabel }}$ 1,66571 dan nilai signifikansi yang diperoleh adalah $0,001<0,05$, maka $\mathrm{H}_{0}$ ditolak $\mathrm{H}_{1}$ diterima, yang artinya variabel Ukuran Perusahaan berpengaruh signifikan terhadap Peringkat Obligasi pada perusahaan publik non keuangan yang terdaftar di PEFINDO periode 20162018.

Dari Tabel 4 tersebut, maka persamaan regresi yang dihasilkan atas analisis variabel independen terhadap Peringkat Obligasi pada perusahaan publik non keuangan yang terdaftar di PEFINDO periode 2016-2018, yaitu sebagai berikut:

\begin{tabular}{|c|c|}
\hline Peringkat & Obligasi $=-7,189+$ \\
\hline & 0,16Likuiditas \\
\hline & 0,273 Leverage $\quad+$ \\
\hline & $\begin{array}{l}0,692 \text { UkuranPerusaha } \\
\text { an }\end{array}$ \\
\hline
\end{tabular}

4.3. Koefisien Determinasi $\left(\mathbf{R}^{2}\right)$ Tabel 5 Koefisien Determinasi

\begin{tabular}{|l|l|l|l|l|}
\hline & & & & $\begin{array}{l}\text { Std. } \\
\text { Error of } \\
\text { the }\end{array}$ \\
Model & R & R Square & $\begin{array}{l}\text { Adjusted } \\
\text { R Square }\end{array}$ & Estimate \\
\hline 1 & .400 & .160 & .126 & 2.072 \\
\hline $\begin{array}{l}\text { a. Predictors: (Constant), } \\
\text { Ukuran_Perusahaan, Likuiditas, Leverage } \\
\text { b. Dependent Variable: Peringkat_Obligasi }\end{array}$ \\
\hline
\end{tabular}


Berdasarkan hasil pengujian koefisien determinasi pada Tabel 5 menunjukkan nilai Adjusted R Square yang diperoleh sebesar 0,126, yang berarti pengaruh Peringkat Obligasi mampu dijelaskan oleh Likuiditas, Leverage dan Ukuran Perusahaan, sebesar 0,126 atau sebesar $12,6 \%$, sedangkan sisanya sebesar 0,874 atau sebesar $87,4 \%$ dijelaskan oleh variabel lain yang tidak diteliti dalam penelitian ini

\subsection{Pengujian Moderasi}

Tabel 6 Hasil Pengujian Moderasi

\begin{tabular}{|c|c|c|c|c|c|c|}
\hline \multirow{2}{*}{\multicolumn{2}{|c|}{ Model }} & \multicolumn{2}{|c|}{$\begin{array}{l}\text { Unstandardized } \\
\text { Coefficients }\end{array}$} & \multirow{2}{*}{\begin{tabular}{|l} 
Standardized \\
Coefficients \\
Beta
\end{tabular}} & \multirow[b]{2}{*}{$\mathrm{t}$} & \multirow[b]{2}{*}{ Sig. } \\
\hline & & B & Std. Error & & & \\
\hline \multirow[t]{8}{*}{1} & (Constant) & 14.302 & .591 & & 24.201 & .000 \\
\hline & Zscore (Likuiditas) & .830 & .470 & .375 & 1.765 & .082 \\
\hline & Zscore (Leverage) & -.091 & .444 & -.041 & -.204 & .839 \\
\hline & \begin{tabular}{|l} 
Zscore \\
(Ukuran_Perusahaan)
\end{tabular} & .916 & 216 & .413 & 4.245 & .000 \\
\hline & Zscore (Profitabilitas) & 1.683 & .460 & .759 & 3.660 & .000 \\
\hline & Likuiditas_Profitabilitas & -.813 & .506 & -.444 & -1.606 & .113 \\
\hline & Leverage_Profitabilitas & .086 & .504 & .042 & .172 & .864 \\
\hline & $\begin{array}{l}\text { UkuranPerusahaan_Profita } \\
\text { bilitas }\end{array}$ & -.415 & .295 & -.207 & -1.409 & .163 \\
\hline
\end{tabular}

Berdasarkan Tabel 6 diperoleh kesimpulan bahwa:

1. Nilai selisih mutlak

Likuiditas_Profitabilitas memiliki nilai signifikan sebesar $0,113>0,05$ yang berarti Profitabilitas tidak mampu memoderasi hubungan variabel Likuiditas dengan Peringkat Obligasi pada perusahaan publik non keuangan yang terdaftar di PEFINDO periode 2016-2018.

2. Nilai selisih mutlak Leverage_ Profitabilitas memiliki nilai signifikan sebesar 0,864 > 0,05 yang berarti Profitabilitas tidak mampu memoderasi hubungan variabel Leverage dengan Peringkat Obligasi pada perusahaan publik non keuangan yang terdaftar di PEFINDO periode 2016-2018.

3. Nilai selisih mutlak UkuranPerusahaan_ Profitabilitas memiliki nilai signifikan sebesar $0,163>0,05$ yang berarti Profitabilitas tidak mampu memoderasi hubungan variabel
Ukuran Perusahaan dengan Peringkat Obligasi pada perusahaan publik non keuangan yang terdaftar di PEFINDO periode 2016-2018.

\subsection{Pembahasan}

\section{a. Pengaruh Likuiditas Terhadap Peringkat Obligasi dengan Profitabilitas Sebagai Variabel Moderasi}

Dalam penelitian ini likuiditas tidak berpengaruh terhadap peringkat obligasi. Hal ini dapat dikarenakan total aset lancar berisi nilai aset yang likuid lebih tinggi tidak diimbangi dengan ketersediaan kas yang memadai untuk melakukan pembayaran bunga obligasi. Profitabilitas tidak mampu memoderasi hubungan likuiditas terhadap peringkat obligasi. Hal ini disebabkan karena penjualan yang mendukung profit perusahaan tidak semua dalam bentuk tunai namun ada juga yang dalam bentuk kredit. Sehingga, tingkat profitabilitas perusahaan tidak mampu menambah kas perusahaan. 


\section{b. Pengaruh Leverage Terhadap Peringkat Obligasi dengan Profitabilitas Sebagai variabel Moderasi}

Dalam penelitian ini leverage tidak berpengaruh terhadap peringkat obligasi. Hal ini disebabkan karena perusahaan publik non keuangan yang dijadikan observasi pada penelitian ini memiliki nilai leverage yang tinggi tetapi tetap memiliki peringkat obligasi yang tergolong obligasi yang layak diinvestasikan (investment grade) karena walaupun memiliki nilai leverage yang tinggi, perusahaan tetap memiliki laba perusahaan yang stabil sehingga PEFINDO menilai bahwa perusahaan tersebut masih memiliki kemampuan melakukan pembayaran obligasinya. Profitabilitas tidak mampu memoderasi hubungan leverage terhadap peringkat obligasi. Hal ini dikarenakan profit tidak lagi menjadi acuan bagi kreditor dalam memutuskan untuk membeli obligasi sebuah perusahaan melainkan lebih kepada reputasi perusahaan dipasar

\section{c. Pengaruh Ukuran Perusahaan Terhadap Peringkat Obligasi dengan Profitabilitas Sebagai Variabel Moderasi}

Hasil penelitian menunjukkan bahwa variabel ukuran perusahaan berpengaruh signifikan terhadap peringkat obligasi. Hal ini disebabkan oleh aktiva yang dimiliki perusahaan besar relatif lebih banyak jumlahnya sehingga perusahaan dapat menggunakan aktiva yang ada untuk memperoleh keuntungan maksimal dalam mempertahankan keberlangsungan hidup perusahaan. Dengan banyaknya aktiva yang dimiliki perusahaan besar, kemampuan perusahaan meminimalisir risiko obligasi yang diterbitkan akan semakin baik sehingga peringkat obligasi yang diperoleh juga baik. Profitabilitas tidak mampu memoderasi hubungan ukuran perusahaan terhadap peringkat obligasi. Hal ini disebabkan karena perusahaan yang besar telah memiliki asset sebagai jaminan hutang, sehingga kreditor tidak lagi memperhatikan kemampuan perusahaan dalam menghasilkan profit.

\section{KESIMPULAN DAN SARAN}

Berdasarkan hasil penelitian Secara simultan Likuiditas, Leverage dan Ukuran Perusahaan berpengaruh signifikan terhadap Peringkat Obligasi pada perusahaan publik non keuangan yang terdaftar di PEFINDO periode 2016-2018. Secara parsial, Ukuran Perusahaan berpengaruh signifikan terhadap Peringkat Obligasi pada perusahaan publik non keuangan yang terdaftar di PEFINDO periode 2016-2018. Sedangkan Likuiditas dan Leverage tidak berpengaruh terhadap Peringkat Obligasi pada perusahaan publik non keuangan yang terdaftar di PEFINDO periode 20162018. Profitabilitas tidak mampu memoderasi hubungan antara antara Likuiditas, Leverage dan Ukuran Perusahaan dengan Peringkat Obligasi pada perusahaan publik non keuangan yang terdaftar di PEFINDO periode 20162018

Beberapa saran yang dapat diberikan berdasarkan hasil penelitian yang telah dilakukan adalah diharapkan peneliti selanjutnya dapat menambahkan faktor non keuangan seperti umur obligasi. Suatu perusahaan yang mengeluarkan obligasi dengan jangka waktu jatuh tempo lebih singkat akan menarik minat investor karena risiko yang ditanggung investor akan lebih rendah daripada obligasi dengan jangka waktu jatuh tempo yang lebih panjang.

\section{REFERENSI}

Azani, P. K., Khairunnisa, \& Dillak, V. J. (2017). Pengaruh Likuiditas, Leverage dan Pertumbuhan Perusahaan terhadap Peringkat Obligasi (Studi Empiris Pada 
Perusahaan Non Perbankan yang Diperingkat oleh PT. PEFINDO Tahun 2011-2015). e-Proceeding of Management, 4, No.1(ISSN : 23559357), 387-394

Brigham, E. F., \& Houston, J. F. (2010). Dasar - Dasar Manajemen Keuangan. Jakarta: Salemba Empat

Fauziah, Y. (2014). Pengaruh Likuiditas, Leverage, dan Umur Obligasi terhadap Prediksi Peringkat Obligasi (Studi Empiris pada Perusahaan yang Terdaftar di Bursa Efek Indonesia Tahun 2009-2012). Jurnal Akuntansi, Vol. 2, No. 1, ISSN: 14123290.

Ghozali, I. (2013). Aplikasi Analisis Multivariate Dengan Program IBM SPSS 23. Semarang: Badan Penerbit Universitas Diponegoro.

Hartono, J. (2017). Teori Portofolio dan Analisis Investasi. Yogyakarta: BPFE Yogyakarta

Hery. (2017). Kajian Riset Akuntansi Mengulas Berbagai Hasil Penelitian Terkini dalam Bidang Akuntansi Keuangan. Jakarta: PT. Grasindo.

Kasmir. (2018). Analisis Laporan Keuangan (ke 11 ed.). Rajawali

Kustiyaningrum, D., Elva Nuraina, Anggita Langgeng Wijaya (2016). Pengaruh Leverage, Likuiditas, Profotabilitas, dan Umur Obligasi Terhadap Peringkat Obligasi (Studi pada Perusahaan Terbuka yang Terdaftar di Bursa Efek Indonesia), Jurnal Akuntansi dan Pendidikan, vol. 5 Nomor 1

Novita, N. (2018). Pengaruh Rasio Keuangan Terhadap Peringkat Obligasi Pada Perusahaan Non Keuangan Di BEI Tahun 2013-2016. Jurnal Ekobis Dewantara, 1.

Pefindo. (2019). www.Pefindo.com. Retrieved

from http://www.pefindo.com/index.php/f ileman/file?=95

Reyssent, D. (2016). Analisis FaktorFaktor Yang Mempengaruhi

Peringkat Obligasi Pada Perusahaan Keuangan Yang Terdaftar Di BEI Tahun 2012-2014, Ultima Accounting, vol. 8.

Safitri, A (2014). Analisis Faktor-Faktor Yang Mempengaruhi Peringkat Obligasi Perusahaan Manufaktur Yang Terdaftar Di Bursa Efek Indonesia, Jurnal Bisnis Administrasi.

Sari, N. S., \& Badjra, I. B. (2016). Pengaruh Likuiditas, Ukuran Perusahaan, Leverage, dan Jaminan Tterhadap Peringkat Obligasi pada Sektor Keuangan. E-jurnal Manajemen Unud, 5, No 8(ISSN: 2302-8912), 5041-5069

Sihombing, H. J., \& Rachmawati, E. N. (2015). Faktor-Faktor Yang Mempengaruhi Peringkat Obligasi Pada Perusahaan Yang Terdaftar Di Bursa Efek Indonesia. Jurnal Ekonomi, Manajemen dan Akuntansi I, 24, No 1, 95-118.

Sitorus, P. Tarmiden, Pasar Obligasi Indonesia: Teori dan Praktik, vol. I, Jakarta: PT RajaGrafindo Persada, 2015.

Vina, (2017). Analisis Pengaruh Reputasi Auditor, Umur Obligasi, Likuiditas, Growth, dan Produktivitas Perusahaan Terhadap Peringkat Obligasi Pada Perusahaan Go Public Yang Terdaftar Di Bursa Efek Indonesia," Jurnal Akuntansi Bisnis, Vol. VX,

Wijayanti, I., \& Priyadi, M. P. (2014). Faktor-Faktor yang Mempengaruhi Peringkat Obligasi. Jurnal Ilmu \& Riset Akuntansi, 3, No 3, 1-15 